\title{
Verbalisasi Moderasi Beragama dalam Artikel Sarjana PTKIN Indonesia 2016-2020
}

\author{
Abdul Malik \\ Universitas Al-Asy'ariyah Mandar, Sulawesi Barat, Indonesia \\ abdulmalik@mail.unasman.ac.id \\ M. Anwar Hindi \\ Universitas Al-Asy'ariyah Mandar, Sulawesi Barat, Indonesia \\ anwarhindi@gmail.com
}

\begin{abstract}
The Indonesian Minister of Religion, Lukman Hakim Saifuddin, Fachrul Razi and Yaqul Cholil Qoumas, always gave directions to the Indonesian people to make religious moderation a shared commitment. One of the important elements of the implementation of religious moderation is carried out by scholar of Indonesian PTKIN in the form of reviewing journal articles. This article analyzes religious moderation in Indonesian PTKIN scholarships recorded in the form of journal articles from the first edition of 2016 to the second edition of 2020. To analyze these various articles, Verbalization will be adopted which was originally used to analyze the Qur'an for religious moderation. The Verbalization method, coined by Muhammad Alwi HS, has a strong epistemology, because it is based on the orallity of Qur'an which is the initial form as well as the identity of the Qur'an. Finally, this article concludes that PTKIN scholars are active in responding to the issue of religious moderation, which is carried out with various perspectives and scopes. What is more important is that almost all PTKIN scholars make efforts to verbalize religious moderation to the context or scope of their studies. This scholar is an important contribution of PTKIN scholars to efforts to produce patterns, guard, and develop religious moderation in Indonesia, especially since 2016-2020.
\end{abstract}

Keywords: Scholar of PTKIN, Verbalization, Religious Moderation, and Journal Articles.

\begin{abstract}
Abstrak
Menteri Agama RI, Lukman Hakim Saifuddin, Fachrul Razi dan Yaqul Cholil Qoumas, senantiasa memberi arahan kepada masyarakat Indonesia agar menjadikan moderasi beragama sebagai komitmen bersama. Salah satu elemen penting pelaksanaan moderasi beragama tersebut dilakukan oleh para Sarjana PTKIN Indonesia dalam bentuk kajian artikel jurnal. Artikel ini menganalisis moderasi beragama dalam kesarjanaan PTKIN Indonesia yang terekam dalam bentuk artikel jurnal dari edisi pertama 2016 hingga edisi kedua 2020.Untuk menganalisis berbagai artikel tersebut, akan diadopsi Verbalisasiyang semula digunakan untuk menganalisis Al-Qur'an kepada moderasi beragama. Metode Verbalisasi, dicetuskan oleh Muhammad Alwi HS, memiliki epistemologi yang kuat, karena ia berlandaskan pada kelisanan Al-Qur'an yang merupakan bentuk awal sekaligus jati diri Al-Qur'an. Akhirnya, artikel ini menyimpulkan bahwa sarjana PTKIN aktif dalam merespon isu moderasi beragama, yang dilakukan dengan ragam perspektif dan
\end{abstract}


lingkup.Yang lebih penting adalah hampir seluruh sarjana PTKIN melakukan upaya Verbalisasi terhadap moderasi beragama kepada konteks atau lingkup kajiannya.Dengan Verbalisasi moderasi beragama, berbagai artikel sarjana tersebut menjadi sumbangsih penting sarjana PTKIN terhadap upaya menghasilkan pola, penjagaan, hingga pengembangan moderasi beragama di Indonesia, terutama sejak 2016-2020.

Kata Kunci: Sarjana PTKIN, Verbalisasi, Moderasi Beragama, dan Artikel Jurnal.

\section{A. PENDAHULUAN}

Isu moderasi beragama senantiasa menjadi isu nasional, sebagaimana dalam arahan Lukman Hakim Saifuddin, Menteri Agama RI 2014-2019, bahwa moderasi beragama mesti menjadi komitmen bersama dalam mewujudkannya. ${ }^{1}$ Komitmen ini terus berlanjut ke jabatan Fahrul Razi, Menteri Agama RI 2019-2020, hingga Yaqul Cholil Qoumas, Menteri Agama 2020-sekarang. Lebih jauh, komitmen tersebut dapat ditinjau dari peran sarjana Indonesia merespon moderasi beragama dalam bentuk artikel jurnal, yang beriringan dengan kewajiban mempublikasikan karya ilmiah dalam bentuk jurnal sejak tahun 2012, baik strata S1, S2, apalagi S3, ${ }^{2}$ termasuk jurnal setiap PTKIN Indonesia yang berada di bawah naungan Kementrian Agama. Bagi sarjana Islam di Indonesia, isu moderasi senantiasa ditempatkan pada tema besar dalam berbagai kegiatan akademisi, baik skala nasional maupun internasional. Annual Internasional Conference Islamic Studies (AICIS) misalnya, agenda para akademisi di bawah naungan Kementrian Agama, selama $2018^{3}$ dan $2019^{4}$ menjadikan isu moderasi beragama sebagai isu besar dalam forum para sarjana Islam tersebut.Di atas kesepakatan visi moderasi beragama tersebut, penting disadari bahwa pra-pemahaman ${ }^{5}$ yang dimiliki satu sarjana dengan sarjana lainnya saling berbeda, yang sangat mungkin menghasilkan keragaman perspektif dalam kajiannya tentang moderasi beragama.

${ }^{1}$ Lukman Hakim Saifuddin, "Sambutan Mentri Agama Republik Indonesia” dalam Tim Penyusun Kementrian Agama RI. Moderasi Beragama, (Jakarta: Kementrian Agama RI, 2019); Tim Penulis, Mozaik Moderasi Beragama dalam Perspektif Islam, (Jakarta: Direktorat Jenderal Bimbingan Masyarakat Kristen Kementrian Agama Republik Indonesia, 2018).

${ }^{2}$ https://lldikti12.ristekdikti.go.id/2012/02/01/surat-dirjen-dikti-no-152et2012-tentang-wajibpublikasi-ilmiah-bagi-s1s2s3.html diakses pada 27 November 2019.

${ }^{3}$ http://diktis.kemenag.go.id/aicis/2018/index.php/2018/10/05/ini-lima-poin-hasil-pertemuansarjana-muslim-dunia/ diakses pada 27 November 2019.

${ }^{4}$ http://diktis.kemenag.go.id/aicis/index.php/2019/10/06/aicis-2019-tiga-rekomendasi-sikapifenomina-digital-islam/ diakses pada 27 November 2019.

5 Gadamer "Text and Interpretation" dalam B.R. Wachterhauser (ed), Hermeneuticand Modern Philosohpy, (New York: Albany State Universityof New YorkPress, 1986). 
Namun demikian, sekalipun beragam perspektif yang muncul, tetapi upaya menyampaikan makna moderasi beragama ke dalam konteks Indonesia menjadikan berbagai kajian sarjana dapat ditinjau dan dianalisis lebih jauh, termasuk dari perspektif Verbalisasi. Di sini, artiki ini akan mengadopsi metode Verbalisasi Al-Qur'an: upaya menyampaikan kembali pemahaman Al-Qur'an dalam konteks yang berbeda dengan konteks pewahyuan, termasuk di Indonesia, ${ }^{6}$ ke dalam kajian moderasi beragama pada artikel jurnal yang ditulis sarjana PTKIN. Verbalisasai pada dasarnya adalah metode penafsiran Al-Qur'an yang dicetuskan oleh Muhammad Alwi HS, alumni UIN Sunan Kalijaga Yogyakarta.Pada dasarnya, metode ini tidak berbeda jauh dengan metode kontekstualisasi ajaran agama lainnya, seperti double movement oleh Fazlur Rahman, kontekstual oleh Abdullah Saeed, dan lainnya.Tetapi, pengambilan metode Verbalisasi di sini dikarenakan metode ini memiliki landasan yang terbaru. Selain itu, metode tersebut memiliki epistemology yang sangat kuat, di mana ia berangkat dari kenyataan Al-Qur'an sebagai teks lisan yang menjadi bentuk awal Al-Qur'an ketika disampaikan pada masa pewahyuan dari Nabi Muhammad ke masyarakat Arab. ${ }^{7}$ Alwi mengatakan bahwa metode Verbalisasiberangkat dari dalil Al-Qur'an, Hadis, serta fakta sejarah. ${ }^{8}$

Kajian pemikiran sarjana dalam bentuk artikel jurnal yang berkaitan dengan studi Islam belum banyak mendapat perhatian dalam penelitian.Sejauh penelusuran penulis, hanya beberapa penelitian yang membahasnya, yakni penelitian Fatimah Fatmawati (2020) tentang "Studi Penelitian Tafsir di Indonesia (Pemetaan Karya Tafsir Indonesia Periode 2011-2018)".9 Penelitian Hariyah (2016) berjudul "Research Trends in Islamic Studies on Journal of Research and Development and Training Center Ministry of Religious Affairs: Using Co-Words". ${ }^{10}$ Penelitian Nailil Huda dan Ade Pahrudin (2018) yang mengkaji tentang “Orientasi Kajian Hadis Kontemporer Indonesia (Studi Artikel E-Jurnal dalam

\footnotetext{
${ }^{6}$ Muhammad Alwi HS, "Verbalisasi Al-Qur'an dan Nilai Pancasila: Legitimasi Surah Al-Maidah/5: 49”, dalam Jurnal Suhuf, Vol. 12, No. 2, 2019.

${ }^{7}$ Muhammad Alwi HS 'Diskursus Kelisanan Al-Qur’an: Membuka Ruang Baru”, dalam Journal of Islamic Studies and Humanities, vol. 4, no. 2, 2020.

${ }^{8}$ Muhammad Alwi HS, "Relasi Kelisanan Al-Qur'an dan Pancasila dalam Upaya Menjaga dan Mengembangkan Identitas Islam Indonesia”, dalam International Journal Ihya Ulum Al-Din, vol. 21, no. 1, 2020.

${ }^{9}$ Fatimah Fatmawati, "Studi Penelitian Tafsir di Indonesia (Pemetaan Karya Tafsir Indonesia Periode 2011-2018)" dalam Al-Tadabbur: Jurnal Kajian Sosial, Peradaban dan Agama, Vol. 6, No. 1, 2020.

${ }^{10}$ Hariyah, "Research Trends in Islamic Studies on Journal of Research and Development and Training Center Ministry of Religious Affairs: Using Co-Words”, dalam Record and Library Journal, Vol. 2, No. 2, 2016.
} 
Portal Moraref 2015-2017)".11 Padahal kedudukan artikel jurnal sangat penting dalam pengembangan keilmuan di dunia akademik, termasuk di kampus-kampus PTKIN seIndonesia. Karena itu, artikel ini akan membahas kajian keislaman dalam artikel-artikel jurnal oleh sarjana dari kampus-kampus PTKIN yang belum banyak disentuh tersebut, dengan berfokus pada fenomena moderasi beragama selama tahun 2016-2020.

Pengambilan sarjana PTKIN Indonesia di sini untuk memperlihatkan ragam peran signifikan para sarjana di lingkungan kampus di bawah naungan Kementrian Agama RIyang selama ini (dan kedepannya) berupaya menyajikan moderasi beragama kepada masyarakat Indonesia. Adapun pemilihan 2016-2020 sebagai tahun penerbitan artikel jurnal, hal ini umumnya jurnal-jurnal menyandarkan referensi artikel jurnal sekitar lima tahun terakhir. Batas lima tahun dalam artikel jurnal berguna menyajikan artikel-artikel terbaru dan ter-update, sehingga proses keilmuan senantiasa terlihat perkembangannya. Dengan demikian, penelitian ini berupaya mengkaji sejauhmana upaya Verbalisasi ayatayat moderasi beragama perspektif sarjana PTKIN, sebagai agen moderasi beragama yang 'terlibat' dalam perjalanan agama di Indonesia, dalam bentuk artikel jurnal, sebagai wadah teru-update tentang perkembangan ilmu pengetahuan dan penelitian. Dari sini, rumusan masalah yang hendak dijawab dalam penelitian ini adalah bagaimana Verbalisasi moderasi beragama pada artikel jurnal di PTKIN Indonesia 2016-2020? dan agaimana dinamika dan ragam Verbalisasi moderasi beragama yang muncul pada artikel jurnal di PTKIN Indonesia 2016-2020?

\section{B. PEMBAHASAN}

\section{Deskripsi Verbalisasi: dari Memahami Al-Qur'an Menuju Moderasi Beragama}

Dalam memahami Al-Qur'an, metode verbalisasi terbilang metode penafsiran AlQur'an yang terbaru. Sudah banyak metode yang lebih dahulu muncul sebelum metode ini, terutama di era modern-kontemporer. Dalam penelusuran penulis, metode penafsiran AlQur'an di era modern-kontemporer dimulai pada munculnya Double Movement yang dicetuskan oleh Fazlur Rahman. ${ }^{12}$ Metode selanjutnya muncul kontekstualisasi yang

\footnotetext{
${ }^{11}$ Nailil Huda dan Ade Pahrudin, "Orientasi Kajian Hadis Kontemporer Indonesia (Studi Artikel EJurnal dalam Portal Moraref 2015-2017”, dalam Refleksi, Vol. 17, No. 2, 2018.

${ }^{12}$ Fazlur Rahman, Islam and Modernitiy: Transformation of an Intellectual Tradition, (Chicago: Chicago University Press, 1982).
} 
dicetuskan oleh Abdullah Saeed. ${ }^{13}$ Lien menilai bahwa metode kontekstualisasi Abdullah Saeed tersebut merupakan lanjutan dari Double Movement. ${ }^{14}$ Selain dua metode tersebut, masih banyak metode lainnya yang digunakan terutama dalam memahami ajaran Islam, baik Al-Qur'an maupun Hadis, yang dimunculkan oleh sarjana Islam seperti metode Ma'na-cum-Maghza dari Sahiron Syamsuddin, metode Tafsir Maqashidi ${ }^{15}$ dari Abdul Mustaqim $^{16}$, metode Verbalisasi Al-Qur'an, dan lainnya.

Berbagai metode tersebut di atas tidak berhenti digunakan hanya pada pemahaman Al-Qur'an atau Hadis, tetapi telah digunakan untuk menganalisis objek kajian yang lebih luas.Teori Double Movoment misalnya, tidak lagi digunakan untuk mengkontekstualisasikan pemahaman Al-Qur'an, tetapi juga digunakan dalam mengkontekstualisasikan Hadis, sebagaimana dilakukan oleh Azkiya Khikmatiar (2018). ${ }^{17}$ Teori Ma'na-cum-Maghza digunakan lebih luas, tidak hanya mengkaji Al-Qur'an dan Hadis, tetapi juga mengkaji perkataan (baca: pesan) manusia, sebagaimana dilakukan oleh Muhammad Alwi HS dalam artikelnya yang berjudul "Mewujudkan Perdamaian di Era Media Versi KH. Maimun Zubair: Analisis Ma’na-cum'Maghza atas Pesan KH. Maimun Zubair di Media Sosial" (2019). ${ }^{18}$ Dengan dasar tersebut, penelitian ini akan menggunakan metode Verbalisasi yang semula digunakan untuk mengkaji Al-Qur'an akan digunakan untuk mengkaji artikel-artikel sarjana PTKIN tahun 2016-2020, khususnya terkait isu moderasi beragama di Indonesia.

Dalam satu artikelnya, Metode Verbalisasi Al-Qur'an muncul sebagaiupaya menjawab kegelisahan Muhammad Alwi HS terhadap perdebatan pemahaman Al-Qur'an yang terjadi di kalangan umat Islam.Ia mengatakan bahwa selama ini umat Islam telah terkotak-kotakkan pada pemahaman Al-Qur'an, di mana pemahaman tersebut berkutat pada Al-Qur'an sebagai teks tulis. Lebih jauh, Muhammad Alwi HS mengatakan bahwa

${ }^{13}$ Abdullah Saeed, Reading the Qur'an in the Twenty-First Century: A Contextualist Approach, (Oxon and New York: Routledge, 2014).

${ }^{14}$ Lien Iffah Naf'atu Fina, "Interpretasi Kontekstual Abdullah Saeed: Sebuah Penyempurnaan Terhadap Gagasan Tafsir Fazlur Rahman”, dalam Jurnal Hermeneutik, Volume 9, Nomor 1, 2015.

15 Sahiron Syamsuddin, Hermeneutika dan Pengembangan Ulumul Qur'an (edisi Revisi dan Pengembangan), (Yogyakarta: Pesantren Nawesea Press, 2017).

${ }^{16}$ Abdul Mustaqim, Al-Tafsir Al-Maqashidi, (Yogyakarta: Idea Press, 2019).

17 Azkiya Khikmatiar, "Reinterpretation of the Hadith of Tashabbuh: Application of the Double Movement Fazlur Rahman's Theory in Understanding the Hadith" dalam Journal of Hadith Studies, Volume 1 Nomor 1, 2018.

${ }^{18}$ Muhammad Alwi HS, "Mewujudkan Perdamaian di Era Media Versi KH. Maimun Zubair: Analisis Ma'na-cum-Maghza atas Pesan KH. Maimun Zubair di Media Sosial", dalam Madinah: Jurnal Studi Islam, Vol. 6, No. 2, 2019. 
pemahaman berbasis tulisan itulah yang membagi pemahaman menjadi tiga kelompok. Abdullah Saeed menyebut tiga kelompok tersebut sebagai tekstualis, semi tekstual, dan kontekstual, Sahorin Syamsuddin menyebutnya sebagai quasi-obyektivis-tradisionalis, subyektivis, quasi-obyektivis-progresif, dan Abdul Mustaqim menyebut tekstualisskripstualis-literalis, de-tekstualis-liberalis, dan Tafsir Maqashidi. ${ }^{19}$

Perdebatan pemahaman tersebut disebabkan karena adanya tiga kelompok pemahaman Al-Qur'an itu sendiri, sehingga seseorang boleh saja tidak memilih pemahaman tertentu, dan memilih pemahaman lainnya. ${ }^{20}$ Dari sini, Muhammad Alwi HS menawarkan metode Verbalisasi yang dinilainya dapat menjadi jembatan yang menghubungkan semua pemahama semua kalangan umat Islam yang selama ini terkotakkotakka. Hal ini karena metode Verbalisasi berlandaskan pada kelisanan Al-Qur'an yang merupakan bentuk awal sekaligus jati diri Al-Qur'an yang hanya melahirkan satu pemahaman, yakni pemahaman kontekstual. ${ }^{21}$

Dilihat dari perjalanannya, tidak ditemukan buku Muhammad Alwi HS yang secara khusus membahas tentang metode Verbalisasi Al-Qur'an.Namun, buku yang mengindikasikan sebagai wacana awal kemunculan metode tersebut telah ditulis, seperti “Pengantar Al-Qur'an dan Hadis untuk Indonesia: Upaya Membaca Sisi Kelisanan A1Qur'an dan Hadis" (2018), ${ }^{22}$ tentang pengungkapan sisi kelisanan Al-Qur'an sebagaimana kelak menjadi dasar munculnya metode Verbalisasi Al-Qur'an. Tesis Muhammad Alwi HS yang berjudul "Kelisanan Al-Qur'an dan Karakteristik Pemahamannya",23 juga menjadi penting dalam kemunculan metode Verbalisasi Al-Qur'an.Karya-karya mengenai metode Verbalisasi Al-Qur'an banyak ditemukan dalam bentuk artikel jurnal, yaitu "Verbalisasi Al-Qur'an: Metode Tafsir Kontekstual Berbasis Kelisanan Al-Qur'an (Studi QS. Al-

\footnotetext{
${ }^{19}$ Muhammad Alwi HS dan Iin Parninsih, "Verbalisasi Al-Qur'an: Metode Tafsir Kontekstual Berbasis Kelisanan Al-Qur'an (Studi QS. Al-Baqarah: 156 tentang Pemaksaan Agama)",dalam Substantia: Jurnal Ilmu-ilmu Ushuluddin, Vol. 22, No. 2, 2020, hlm. 121.

${ }^{20}$ Muhammad Alwi HS dan Iin Parninsih, "Verbalisasi Al-Qur'an: Metode Tafsir Kontekstual Berbasis Kelisanan Al-Qur'an (Studi QS. Al-Baqarah: 156 tentang Pemaksaan Agama)”,hlm. 122.

${ }^{21}$ Muhammad Alwi HS dan Iin Parninsih, "Verbalisasi Al-Qur'an: Metode Tafsir Kontekstual Berbasis Kelisanan Al-Qur'an (Studi QS. Al-Baqarah: 156 tentang Pemaksaan Agama)”, hlm.126.

${ }^{22}$ Muhammad Alwi HS, Pengantar Al-Qur'an dan Hadis untuk Indonesia: Upaya Membaca sisi Kelisanan Al-Qur'an dan Hadis, (Yogyakarta: Deepublish, 2018).

${ }^{23}$ Muh. Alwi HS, "Kelisanan Al-Qur'an dan Karakteristik Pemahamannya (Kajian QS. AlKafirun)", Tesis UIN Sunan Kalijaga Yogyakarta, 2020.
} 
Baqarah: 156 tentang Pemaksaan Agama)" (2020), ${ }^{24}$ dan artikel "Verbalisasi Al-Qur'an dan Nilai Pancasila: Legitimasi Surah Al-Maidah/5:49” (2019). ${ }^{25}$

Sampai di sini, metode Verbalisasi di atas yang semula digunakan dalam menganalisis pemahaman Al-Qur'an akan digunakan dalam menganalisis moderasi beragama yang dijumpai dalam artikel-artikel jurnal oleh para sarjana PTKIN Indonesia dari tahun 2016-2020. Penggunaan metode Verbalisasi di sini dibatasi hanya pada pemahaman "secara kontekstualisasi" dari moderasi beragama menuju keterlibatan ruang lingkup kajian sarjana PTKIN Indonesia. Dalam artian bahwa setiap ruang lingkup yang mengitari diskusi moderasi beragama akan dianalisis adanya tinjauan Verbalisasi di dalamnya, sehingga pemahaman moderasi beragama menjadi lebih kontekstual dan merespon kegelisahan para sarjana PTKIN Indonesia. Di sini, bahasan selanjutnya akan dikemukakan artikel-artikel sarjana PTKIN Indonesia yang membahas moderasi beragama. Dengan melakukan pemetaan artikel-artikel, akan terlihat dinamika kemunculan dan perkembangan kajian moderasi beragama di Indonesia dari tahun 2016-2020.

\section{Pemetaan Ruang Lingkup Moderasi Beragama dalam Artikel Jurnal}

Paparan sebelumnya menjelaskan tentang Verbalisasi sebagai metode yang akan digunakan dalam menganalisis moderasi beragama dalam artikel-artikel jurnal yang ditulis oleh para sarjana PTKIN di Indonesia. Moderasi beragama bertujuan mengaktualisasikan nilai-nilai agama dan budaya luhur dalam berbangsa dan bernegara, sehingga tidak terjadi benturan, kesewenang-wenangan, dan lainnya. ${ }^{26}$ Al-Salabi mengatakan bahwa moderat (moderasi) dalam Al-Qur'an disebut dengan Al-Washathiyah yang secara sederhana bermakna baina (antara). ${ }^{27}$ Senada dengan ini, Hashim Kamali mengatakan bahwa istilah moderasi (Al-Washithiyah) erat kaitannnya dengan keadilan. ${ }^{28}$ Dari pemahaman moderasi beragama ini, penulis menemukan banyak artikel yang ditulis oleh sarjana PTKIN sepanjang edisi pertama 2016 hingga 2020.Sepanjang penelusuran penulis, ditemukan dua

\footnotetext{
${ }^{24}$ Muhammad Alwi HS dan Iin Parninsih, "Verbalisasi Al-Qur'an: Metode Tafsir Kontekstual Berbasis Kelisanan Al-Qur'an (Studi QS. Al-Baqarah: 156 tentang Pemaksaan Agama)", dalam Substantia: Jurnal Ilmu-ilmu Ushuluddin, Vol. 22, No. 2, 2020.

25 Muhammad Alwi HS, "Verbalisasi Al-Qur'an dan Nilai Pancasila: Legitimasi Surah AlMaidah/5:49”, dalam Jurnal Suhuf, vol. 12, No. 2, 2019.

${ }^{26}$ Departemen Agama RI, Etika Berkeluarga, Bermasyarakat dan Berpolitik, Cet. 1 (Jakarta: Lajnah Pentashihan Mushaf Al-Qur'an, 2009), hlm. 91.

${ }^{27}$ Ali Muhammad Muhammad al-Salabi, al-Wasathiyyah fi al-Qur'an al-Karim (Kairo: Maktabah at-Tabi’în, 2001), 13-14.

${ }^{28}$ Mohammad Hashim Kamali, The Middle Path of Moderation in Islam: the Qur'anic Principle of Wasathiyyah (New York: Oxford University Press, 2015), hlm. 9
} 
puluh tujuh (27) artikel jurnal yang ditulis oleh para sarjana PTKIN, yang didominasi oleh IAIN dan UIN.Isu moderasi beragama dalam artikel-artikel tersebut dapat diklasifikasi ke beberapa pemetaan, mulai konteks Indonesia secara umum, organisasi masyarakat (ORMAS) Islam, lembaga pendidikan, hingga moderasi beragama di ruang media sosial.

Pertama, Moderasi beragama dalam lingkup keindonesiaan secara umum.Pada bagian ini, artikel terkait moderasi beragama ditemukan secara beragam, baik kajian lapangan maupun konseptual.Paling tidak, ditemukan sembilan artikel tentang moderasi beragama yang ditemukan di tahun yang berbeda-beda, dari tahun 2017-2020.Artikel tentang moderasi beragama yang terkait Islam di Indonesia yang ditemukan pada tahun 2017 adalah "Mengusung Moderasi Islam di tengah Masyarakat Multi Kultural" oleh Darlis, dan "Islam Wasatiyyah: Refleksi Antara Islam Modern dan Upaya Moderasi Islam" oleh Mohammad Deny Irawan. Pada tahun 2018 ditemukan artikel moderasi beragama berjudul "Radikalisme Islam VS Moderasi Islam: Upaya Membangun Wajah Islam Indonesia yang Damai” oleh Nurul Faiqah dan Toni Pransiska, dan artikel berjudul "Moderasi Islam, untuk Peradaban dan Kemanusiaan" oleh Ahmad Fauzi. Pada tahun 2019, muncul artikel moderasi beragama terkait Islam, yang tidak jauh berbeda dengan artikel yang ditulis Deny Irawan di atas.Artikel tersebut adalah "Moderasi Islam (Wasathiyyah) di Tengah Pluralisme Agama Indonesia" oleh Busyro, Aditiya Hari Ananda dan Tarihoran Sanur Adlan. Artikel selanjutnya adalah "Moderasi Islam dan Akulturasi Budaya: Revitalisasi Kemajuan Peradaban Islam Nusantara” oleh Ahmad Khoiri.

Pada tahun 2020, muncul artikel "Moderasi Beragama di Tengah Pluralitas Bangsa: Tinjauan Revolusi Mental Perspektif Al-Qur'an” oleh Khalil Nurul Islam yang secara spesifik mengambil sudut pandang Al-Qur'an. Selanjutnya, artikel yang lebih luas lingkupnya adalah "Moderasi Beragama di Indonesia" oleh Mohammad Fahri dan Ahmad Zainuri (2019) dapat diposisikan sebagai artikel yang paling luas cakupan lingkupnya dari dua artikel sebelumnya di atas. Namun, artikel tersebut memperlihatkan pembahasan yang tidak jauh berbeda dengan artikel "Moderasi Islam (Wasathiyyah) di Tengah Pluralisme Agama Indonesia" oleh Busyro, Aditiya Hari Ananda dan Tarihoran Sanur Adlan sebagaimana telah dijelaskan sebelumnya. Hampir tidak ditemukan kebaharuan dalam artikel tersebut, hal ini karena paparan pembahasan dan kesimpulan yang dicapai sangat mirip dengan pembahasan artikel Busyro, Aditiya Hari Ananda dan Tarihoran Sanur Adlan. 
Kedua, Moderasi Beragama dalam kaitannya dengan Pemerintahan Indonesia. Dalam konteks ini, ditemukan dua artikel yang terbit pada tahun 2019 dan 2020. Artikel pertama berjudul "Moderasi Islam, Pencantuman Penghayat Kepercayaan di Kolom KTP/KK dalam Nalar Maqasid oleh Hamka Husein Hasibuan (2019) dan "Pesan Kementrian Agama dalam Moderasi Melalui Media Sosial Instagram” oleh RR. Wuri Arenggoasih dan Corona Raisa Wijayanti (2020).Kedua artikel tersebut mengambil perspektif yang berbeda, di mana artikel pertama berfokus pada analisis kritis terhadap Nalar Maqasid atas pencantuman identitas Penghayat Kepercayaan di kolom KTP/KK, sementara yang kedua merupakan siaran dakwah moderasi beragama oleh kementrian Agama di media sosial.

Ketiga, Moderasi Beragama dalam konteks Organisasi Masyarakat (ORMAS) Islam Indonesia.Di sini, ada empat artikel yang membahas isu moderasi beragama, tahun 2017 (1 artikel), 2018 (2 artikel), dan di tahun 2020 (1 artikel). Pada tahun 2017, artikel yang ditemukan berjudul "Muhammadiyah dan NU: Penjaga Moderatisme Islam di Indonesia" oleh Zakiyah Darajat. Tahun 2018 ditemukan artikel "Quo Vadis Ormas Islam Moderat Indonesia? Menoropong Perang NU-Muhammadiyah di Era Revolusi Industri 4.0" oleh Mustiqowati Ummul Fithriyyah dan Muhammad Saiful Umam, "Islam Nusantara: Moderasi Islam di Indonesia" oleh Ahmad Agis Mubarok dan Diaz Gandara Rustam. Adapun tahun 2020 ditemukan artikel berjudul "Akar Sejarah Moderasi Islam pada Nahdlatul Ulama" oleh A. Jauhar Fuad. Tiga artikel tersebut membahas ORMAS Nahdlatul Ulama dan Muhammadiyah, dan satu artikel pada Nahdlatul Ulama.

Keempat, Moderasi Beragama pada lini pendidikan.Dalam konteks ini, penulis menemukan enam artikel jurnal yang membahas moderasi beragama dalam konteks pendidikan, yang muncul pada tahun 2016 (1 artikel), 2019 (1 artikel), dan 2020 (4 artikel). Artikel-artikel tersebut adalah "Peran Pesantren As'adiyah Sengkang dalam Membangun Moderasi Islam di Tanah Bugis (Sebuah Penelitian Awal)" oleh Darlis (2016), "Pondok Pesantren sebagai Wadah Moderasi Islam di Era Generasi Millenial” oleh Neny Muthi'atul Awwaliyah (2019), "Lanskap Moderasi Keagamaan Santri, Refleksi Pola Pendidika Pesantren" oleh Saifudin Asrori (2020), "Nilai Moderasi Islam dan Internalisasinya di Sekolah" oleh M.A. Hermawan (2020), "Penerapan Nilai-nilai Moderasi Islam dalam Pembelajaran Fiqh di PTKIN Menggunakan Konsep ProblemBased Learning" oleh Hani Hiqmatunnisa dan Ashif Az-Zafi (2020), dan "Upaya 
Menyemai Moderasi Beragama Mahasiswa IAIN Kudus melalui Paradigma Ilmu Islam Terapan” oleh Nur Salamah, Muhammad Arief Nugroho, dan Puspo Nugroho (2020).

Sebagian besar berbagai artikel di atas memperlihatkan pesantren sebagai basis pendidikan yang dijadikan objek kajian moderasi beragama.Lini pendidikan lainnya adalah Sekolah dan PTKIN yang semuanya hanya muncul masing-masing satu artikel.Lebih jauh, kajian artikel tentang moderasi beragama di pesantren terbagi menjadi dua, yakni kajian konseptual dan kajian lapangan (konkrit).Artikel yang membahas moderasi beragama secara konseptual sebagaimana dilakukan oleh Neny Muthi'atul Awwaliyah dan Saifudin Asrori. Sementara artikel yang berbasis lapangan sebagaimana dilakukan Darlis.Artikel moderasi beragama di sekolah dilakukan dengan kajian konseptual sebagaimana dilakukan oleh M.A. Hermawan. Adapun moderasi beragama di PTKIN dilakukan dengan kajian lapangan sebagaimana Hani Hiqmatunnisa dan Ashif Az-Zafi, dan di IAIN Kudus sebagaimana dilakukan oleh Nur Salamah, Muhammad Arief Nugroho, dan Puspo Nugroho. Dengan demikian, semua artikel di atas tidak hanya memperlihatkan keragaman lini pendidikan, tetapi juga dari aspek keragamaan bentuk kajiannya.

Kelima, Moderasi Beragama pada tempat Ibadah.Untuk konteks tempat Ibadah, penulis hanya menemukan satu artikel, yakni "Dinamika Pengarusutamaan Moderasi Islam di Masjid Nasional Al-Akbar Surabaya (MAS)" oleh Muktafi (2018).Keenam, Moderasi Beragama yang terkait dengan isu kesetaraan gender, yang penulis temukan dalam artikel "Moderasi Islam dalam Kesetaraan Gender (Komparasi terhadap Agama Yahudi dan Nasrani)" oleh Meirison, Desmadi Saharuddin, Rosdialena dan Muhammad Ridho yang terbit pada tahun 2020. Ketujuh, Moderasi Beragama dalam ruang media sosial.Mengenai moderasi beragama yang dikaitkan dengan konteks media sosial sebenarnya penulis menemukan tiga artikel, yaitu "Pesan Kementrian Agama dalam Moderasi Melalui Media Sosial Instagram" oleh RR. Wuri Arenggoasih, Corona Raisa Wijayanti (2020), "Media dan Dakwah Moderasi: Melacak Peran Strategis dalam Menyebarkan Faham Moderasi di Situs Nahdlatul Wathan On-Line Situs Kalangan Netizen Muslim-Santri” oleh Fahrurrozi dan Muhammad Thohri (2019) dan "Kampanye Moderasi Beragama di Facebook: Bentuk dan Strategi Pesan" oleh Ari Wibowo (2019). Tetapi, artikel yang ditulis oleh Wuri dan Corona Raisa telah dipaparkan sebelumnya, tepatnya pada sub bab Moderasi Beragama dan Pemerintah Indonesia. 
Kedelapan, Moderasi Beragama dalam kaitannya dengan masa Pandemi Covid19.Dalam penelusuran penulis, ditemukan dua artikel yang membahas tentang moderasi beragama terkait dengan masa Pandemi Covid-19, yaitu "Darurat Moderasi Beragama di Tengah Pandemi Corona Virus Desease 2019 (Covid-19)” oleh Abdul Syatar, Muhammad Majdy Amiruddin, Arif Rahman (2020), dan "Membumikan Nilai-nilai Moderasi Agama di Masa Pandemi (dalam Perspektif IPS)" oleh Dany Miftah M. Nur, Mochamad, dan Risha Fitriani (2020).Artikel pertama menggambarkan kekhawatiran atas 'terganggunya' moderasi beragama yang disebabkan oleh penyebaran virus Corona di Indonesia.Sementara artikel kedua berupaya mendakwahkan ajaran agama terkait moderasi beragama meski di masa pandemi, hal ini dianalisis berdasarkan perspektif IPS.

Berbagai artikel dalam tabel di atas memberi pemahaman bahwa artikel tentang isu moderasi beragama telah muncul pada tahun 2016 sebagaimana yang tulisan Darlis, sarjana IAIN Palu.Pada edisi jurnal-jurnal berikutnya memperlihatkan adanya perkembangan atau pertambahan jumlah artikel dari tahun ke tahun.Di sini, artikel tentang moderasi beragama yang paling sedikit ditermukan di tahun 2016, sebagaimana ditulis oleh Darlis. Sementara itu, artikel yang terbanyak ditemukan pada tahun 2020, yang di dalamnya terdapat sepuluh artikel: (1) Betria Zarpina Yanti dan Doli Witro, (2) Meirison, Desmadi Saharuddin, Rosdialena dan Muhammad Ridho, (3) RR. Wuri Arenggoasih, Corona Raisa Wijayanti, (4) Saifuddin Asrori, (5) M.A. Hermawan, (6) Hani Hiqmatunnisa dan Ashif Az-Zafi, (7) Khalil Nurul Islam, (8) A. Jauhar Fuad, (9) Dany Miftah M. Nur, Mochamad, dan Risha Fitriani, (10) Nur Salamah, Muhammad Arief Nugroho, dan Puspo Nugroho. Jumlah artikel yang ditemukan dari tahun ke tahun mengalami perbedaan, pada tahun 2016 hanya ditemukan satu artikel, tahun 2017 ditemukan dua artikel, tahun 2018 ditemukan empat artikel, tahun 2019 ditemukan enam artikel, dan tahun 2020 ditemukan dua belas artikel.

\section{Upaya Sarjana dalam Memverbalisasi Moderasi Beragama}

Bahasan sebelumnya telah dijelaskan mengenai klasifikasi moderasi beragama berbagai dalam berbagai lingkup. Di sana memperlihatkan bahwa moderasi beragama telah menjadi perhatian penting dalam kesarjanaan sejak tahun 2016-2020. Lebih jauh, perhatian terhadap moderasi beragama memunculkan ragam perspektif yang menarik dianalisis lebih jauh, termasuk dari segi tinjauan Verbalisasi.Sebagaimana yang telah dijelaskan 
Verbalisasi yang dipahami dalam penelitian ini adalah upaya menyampaikan kembali pemahaman moderasi beragama ke dalam konteks pengkajinya. Melalui Verbalisasi moderasi beragama tersebut, bagian ini akan memperlihatkan sejauhmana sarjana memahami moderasi beragama secara kontekstual dalam lingkup kajiannya.

Dimulai dari isu moderasi beragama dalam konteks Indonesia secara umum, di sana terdapat artikel Darlis yang berjudul "Mengusung Moderasi Islam di tengah Masyarakat Multikultural”. Dalam artikel tersebut, Darlis mengangkat aspek penting dalam Islam seperti aqidah, syari'ah, tafsir, tasawuf, dan dakwah, yang kemudian menarik benang merah dari aspek-aspek tersebut ke dalam nilai-nilai universal seperti keadilan, persamaa, keseimbangan, fleksibilitas, kemudahan, dan toleransi. ${ }^{29}$ Nilai-nilai tersebut dapat dibaca sebagai upaya Verbalisasi dari segi bentuk ajaran spesifik menuju nilai yang universal. ${ }^{30}$ Artikel selanjutnya ditulis oleh Mohammad Deny Irawan yang menulis "Islam Wasathiyyah: Refleksi antara Islam Modern dan Upaya Moderasi Islam". Upaya Verbalisasi oleh Deny Irawan terlihat dari paparannya yang mengangkat konsep washatiyah dalam menerapkan harmonisasi hubungan antar agama-agama di Indonesia, dan antar agama dengan negara Indonesia itu sendiri. ${ }^{31}$ Artikel "Radikalisme Islam VS Moderasi Islam: Upaya Membangun Wajah Islam Indonesia yang Damai” yang ditulis oleh Nurul Faiqah dan Toni Pransiska tidak memperlihatkan adanya upaya Verbalisasi moderasi beragama. Hal ini karena Nurul Faiqah dan Toni Pransiska berfokus pada argumentasi penolakan radikalisme Islam dengan menawarkan konsep moderasi Islam.

Masih dalam konteks keindonesiaan secara umum, isu moderasi beragama lainnya ditulis oleh Ahmad Fauzi berjudul "Moderasi Islam, untuk Peradaban dan Kemanusiaan".Dalam artikel tersebut, Verbalisasi moderasi beragama terlihat dari bagaimana Ahmad Fauzi menerapkan konsep moderasi beragama dalam bentuk pendidikan. Di sana, Ahmad Fauzi menjadikan manawarkan nilai moderasi Islam sebagai tatanan sosial dalam membangun karakter siswa yang berperadaban. ${ }^{32}$ Artikel selanjutnya berjudul "Moderasi Islam (Wasathiyyah) di Tengah Pluralisme Agama Indonesia" oleh

\footnotetext{
${ }^{29}$ Umar Faruq Thohir. 2016. "Paradigma Hukum Islam; Dari Klasik Menuju Kontemporer". AsySyari'ah : Jurnal Hukum Islam 2 (2), 277.

${ }^{30}$ Darlis, "Mengusung Moderasi Islam di tengah Masyarakat Multi Kultural", dalam Rausyan Fikr, Vol. 13, No. 2, 2017.

31 Mohammad Deny Irawan, "Islam Wasatiyyah: Refleksi Antara Islam Modern dan Upaya Moderasi Islam”, dalam Tajdid, Vol. XVI, No. 2, 2017.

32 Ahmad Fauzi, "Moderasi Islam, untuk Peradaban dan Kemanusiaan", dalam jurnalislam Nusantara, Vol. 2, No. 2, 2018.
} 
Busyro, Aditiya Hari Ananda, dan Tarihoran Sanur Adlan. Dalam artikel tersebut, Verbalisasi moderasi beragama terlihat pada Moderasi sebagai tolak ukur Islam dalam menilai agama lainnya. Dari sini, Verbalisasi muncul dalam bentuk tasamuh (toleransi), syurah (musyawarah) antar agama, serta musawah (tidak diskriminatif). ${ }^{33}$ Artikel selanjutnya ditulis oleh Ahmad Khoiri dengan judul "Moderasi Islam dan Akulturasi Budaya: Revitalisasi Kemajuan Peradaban Islam Nusantara”. Melalui artikel tersebut, dapat dibaca upaya Verbalisasi moderasi beragama oleh Ahmad Khaori dari segi menjadikan moderasi beragama sebagai sisi ontologis dalam memformulasi keberagamaan Islam di Indonesia. ${ }^{34}$

Artikel selanjutnya berjudul "Moderasi Beragama di Tengah Pluralitas Bangsa: Tinjauan Revolusi Mental Perspektif Al-Qur'an” oleh Khalil Nurul Islam. Dalam artikel tersebut, Khalil Nurul Islam dapat disebut sedang memverbalisasi moderasi beragama berdasarkan upayanya dalam mendeskripsikan pentingnya perwujudan atas pemahaman konsep moderasi beragama dan pluralitas agama, yang berujung pada terciptanya gerakan revolusi mental dalam kehidupan beragama dan berbangsa. ${ }^{35}$ Artikel berjudul "Moderasi Beragama di Indonesia" yang ditulis oleh Mohammad Fahri dan Ahmad Zainuri memperlihatkan upaya Verbalisasi moderasi beragama dalam bentuk sikap beragama yang tawazun (berkeseimbangan), I'tidal (lurus dan tegas), tasamuh (toleransi), musawah (egaliter), syura (musyawarah), ishlah (reformasi), aulawiyah (mendahulukan yang prioritas), tathawwur wa ibtikar (dinamis dan inovatif). ${ }^{36}$ Berbagai sikap beragama tersebut, mengindikasikan tawaran dari Mohammad Fahri dan Ahmad Zainuri untuk memahami moderasi beragama dalam konteks Indonesia.

Selanjutnya adalah moderasi beragama dalam konteks pemerintahan Indonesia.Artikel pertama yang dapat disebutkan di sini adalah "Moderasi Islam, Pencantuman Penghayat Kepercayaan di Kolom KTP/KK dalam Nalar Maqasid” oleh Hamka Husein Hasibuan. Dalam artikel tersebut, upaya Verbalisasi moderasi beragama terlihat ketika maqashid dijadikan oleh Hamka Husein dalam mendialogkan moderasi

${ }^{33}$ Busyro, dkk, "Moderasi Islam (Wasathiyyah) di Tengah Pluralisme Agama Indonesia", dalam Fuadana: Jurnal Kajian Keagamaan dan Kemasyarakatan, Vol. 3, No. 1, 2019.

${ }^{34}$ Ahmad Khoiri, "Moderasi Islam dan Akulturasi Budaya: Revitalisasi Kemajuan Peradaban Islam Nusantara”, dalam Islamadina: Jurnal Pemikiran Islam, Vol. 20, No. 1, 2019.

${ }^{35}$ Khalil Nurul Islam, "Moderasi Beragama di Tengah Pluralitas Bangsa: Tinjauan Revolusi Mental Perspektif Al-Qur'an”, dalam Kuriositas: Media Komunikasi Sosial dan Keagamaan, Vol. 13, No. 1, 2020.

${ }^{36}$ Mohamad Fahri dan Ahmad Zainuri, "Moderasi Beragama di Indonesia", dalam Intizar, Vol. 25, No. 2, Desember 2019. 
beragama kekuatan nalar. Dalam hal ini, Verbalisasi moderasi beragama dalam bentuk pencantuman kepercayaan di kolom ktp/kk yang dinilainya sebagai pembangunan (development) dan hak insani (human right) dalam rangka nation-state. ${ }^{37}$ Artikel selanjutnya adalah tulisan RR. Wuri Arenggoasih dan Corona Raisa Wijayanti berjudul "Pesan Kementrian Agama dalam Moderasi melalui Media Sosial Instagram". Upaya Verbalisasi moderasi beragama dalam artikel tersebut terlihat pada perlibatan media sosial dengan mendorong Kementrian Agama untuk menviralkan postingan moderasi beragama secara terstruktur, massif dan sistematis pada akun-akun instansi yang dinaunginya. ${ }^{38}$

Dalam konteks moderasi beragama pada Organisasi Masyarakat (ORMAS) Islam Indonesia. Dapat disebutkan artikel pertama di sini adalah "Muhammadiyah dan NU: Penjaga Moderatisme Islam di Indonesia" oleh Zakiyah Darajat. Dalam artikel tersebut, upaya Verbalisasi moderasi Islam terlihat pada bagaimana Zakiyah Darajat menempatkan Muhammadiyah dan NU sebagai organisasi masyarakat Islam yang mempertahankan moderasi beragama di Indonesia. ${ }^{39}$ Dua organisasi khas Indonesia tersebut dijadikan simbol moderasi beragama yang khas Indonesia.Artikel selanjutnya adalah "Qua Vadis Ormas Islam Moderat Indonesia? Menoropong Peran NU-Muhammadiyah di Era Revolusi Industri 4.0" ditulis oleh Mustiqowati Ummul Fithriyah dan Muhammad Saiful Umam.

Artikel berjudul "Islam Nusantara: Moderasi Islam di Indonesia" yang ditulis oleh Ahmad Agis Mubarok dan Diaz Gandara Rustam juga memperlihatkan upaya Verbalisasi dengan mendiskusikan Islam Nusantara sebagai alternatif pada wawasan moderasi Islam. Lebih jauh, dalam artikel tersebut juga menyebut NU dan Muhammadiyah sebagai representasi moderasi beragama di Indonesia. ${ }^{40}$ Artikel selanjutnya adalah "Akar Sejarah Moderasi Islam pada Nahdlatul Ulama" ditulis oleh A. Jauhar Fuad. Artikel tersebut memperlihatkan Verbalisasi moderasi beragama dengan menarik kemunculan Nahdlatul Ulama yang, salah satunya, merespon tindakan radikal dalam gerakan Wahabi yang telah menguasai kawasan Jazirah Arab. Lebih jauh, gerakan NU terhadap moderasi beragama

${ }^{37}$ Hamka Husein Hasibuan, "Moderasi Islam, Pencantuman Penghayat Kepercayaan di Kolom KTP/KK dalam Nalar Maqasid”, dalam Al-Qalam: Journal of Islam and Plurality, Vol. 4, No. 2, 2019.

${ }^{38}$ RR. Wuri Arenggoasih dan Corona Raisa Wijayanti, "Pesan Kementrian Agama dalam Moderasi Melalui Media Sosial Instagram”, dalam Jurnalisa, Vol. 6, No. 1, 2020.

39 Zakiyah Darajat, "Muhammadiyah dan NU: Penjaga Moderatisme Islam di Indonesia", dalam Hayulah: Indonesian Journal of Multidisciplinary Islamic Studies, Vol. 1, No. 1, 2017.

40 Ahmad Agis Mubarok dan Diaz Gandara Rustam, "Islam Nusantara: Moderasi Islam di Indonesia”, dalam Journal of Islamic Studies and Humanities, Vol. 3, No. 2, 2018. 
terVerbalisasikan lebih jauh dengan mengusung konsep Islam Nusantara yang merepresentasikan moderasi Islam di Indonesia. ${ }^{41}$

Tema artikel berikutnya adalah moderasi beragama dalam lini pendidikan. Dalam konteks ini, artikel pertama berjudul "Pondok Pesantren sebagai Wadah Moderasi Islam di Era Generasi Millenial" ditulis oleh Neny Muthi'atul Awwaliyah.Pelibatan konteks generasi millennial mengindikasikan adanya upaya Verbalisasi moderasi beragama yang dilakukan oleh Neny. Lebih jauh, di era millineal ini, Neny mengatakan bahwa kondisi moderasi beragama pondok pesantren sangat terkait dengan pemikiran para pemimpinnya.Moderasi beragama ini menjadi karakter para pemimpin pesantren yang akan selalu bersinggungan dengan karakter radikal, liberal, atau lainnya, seiring perubahan zaman. ${ }^{42}$ Artikel selanjutnya berjudul "Lanskap Moderasi Keagamaan Santri, Refleksi Pola Pendidikan Pesantren" oleh Saifudin Asrori.Dalam artikel tersebut, Verbalisasi moderasi beragama terlihat pada upaya Saifudin Asrori mengangkat Pondok Modern Darussalam Gontor sebagai representasi moderasi beragama. Di sana, Saifudin Asrori mengatakan bahwa Darussalam Gontor menjadi pesantren yang menjaga moderasi beragama karena berhasil melestarikan pancajiwa dan motto pesantren, integrasi antara kurikulum formal dan informal. ${ }^{43}$

Artikel Darlis yang berjudul "Peran Pesantren As'adiyah Sengkang dalam Membangun Moderasi Islam di Tanah Bugis (Sebuah Penelitian Awal)" memperlihat Verbalisasi moderasi beragama dengan menampilkan peran pesantren As'adiyah yang kontekstual dan relevan dengan perkembangan zaman.Motto "Saling tolong menolong dalam kebaikan" menjadi hal penting dalam mengangkat pesantren As'adiyah sebagai gerakan moderasi beragama di tanah Bugis. ${ }^{44}$ Artikel berjudul "Nilai Moderasi Islam dan Internalisasinya di Sekolah" oleh M.A. Hermawan juga melakukanVerbalisasi moderasi beragama.Hal ini terlihat pada kurikulum formal dan kurikulum tersembunyi sebagai langkah menginternalisasi nilai moderasi Islam di sekolah. Hermawan menilai bahwa

${ }^{41}$ A. Jauhar Fuad, "Akar Sejarah Moderasi Islam pada Nahdlatul Ulama”, dalam Tribakti: Jurnal Pemikiran Keislaman, Vol. 31, No. 1, 2020.

${ }^{42}$ Neny Muthi'atul Awwaliyah, "Pondok Pesantren sebagai Wadah Moderasi Islam di Era Generasi Millenial”, dalam Islamic Review: Jurnal Riset dan Kajian Keislaman, Vol. 8, No. 1, 2019.

${ }^{43}$ Saifuddin Asrori, "Lanskap Moderasi Keagamaan Santri, Refleksi Pola Pendidikan Pesantren", dalam Jurnal Ilmu Sosial Indonesia (JISI), Vol. 1, No. 1, 2020.

${ }^{44}$ Darlis, "Peran Pesantren As'adiyah Sengkang dalam Membangun Moderasi Islam di Tanah Bugis (Sebuah Penelitian Awal)”, dalam Al-Misbah, Vol. 12, No. 1, 2016. 
dengan menjalankan kedua bentuk kurikulum tersebut secara beriringan, internalisasi moderasi Islam akan optimal dirasakan oleh peserta didik. ${ }^{45}$

Selanjutnya, "Penerapan Nilai-nilai Moderasi Islam dalam Pembelajaran Fiqh di PTKIN Menggunakan Konsep Problem-Based Learning” yang ditulis oleh Hani Hiqmatunnisa dan Ashif Az-Zafi. Dalam artikel tersebut, Verbalisasi moderasi beragama terlihat pada upaya penulis artikel tersebut mengangkat pembelajaran Fiqh berbasis PBL (Problem-Based Learning) yang dinilainya sebagai alternatif penting dalam memperluas wawasan mahasiswa mengenai keragaman pendapat ulama fiqh terhadap sebuah hukum Islam.Dari sini, dosen menjadi agen tak kalah penting dalam mengarahkan mahasiswanya untuk menyikapi keragaman hukum Islam secara moderat. ${ }^{46}$ Artikel selanjutnya berjudul "Upaya Menyemai Moderasi Beragama Mahasiswa IAIN Kudus melalui Paradigma Ilmu Islam Terapan" oleh Nur Salamah, Muhammad Arief Nugroho, dan Puspo Nugroho. Dengan berfokus pada IAIN Kudus, artikel tersebut memperlihatkan Verbalisasi moderas beragama pada tiga langkah strategi penyemai moderasi beragama berbasis Islam Terapan, yaitu menjadikan Ilmu Islam Terapan sebagai mata kuliah, membangun Rumah Moderasi, dan menyelenggarakan kelas IIT. ${ }^{47}$

Dalam konteks moderasi beragama yang terkait dengan kesetaraan gender, ditemukan satu artikel yaitu berjudul "Moderasi Islam dalam Kesetaraan Gender (Komparasi terhadap Agama Yahudi dan Nasrani)" oleh Meirison, Desmadi Saharuddin, Rosdialena dan Muhammad Ridho. Dalam artikel tersebut, Verbalisasi moderasi beragama yang dilakukan oleh empat penulis tersebut terlihat pada upayanya mengaitkan moderasi beragama dengan agama Yahudi dan Nasrani. Dari sini, penulis artikel tersebut menilai bahwa masih terjadi ketimpangan dalam agama-agama tersebut terhadap kesetaraan gender: sebagian pandangan di Yahudi menilai perempuan sebagai barang najis, sebagian pandangan di Nasrani menilai perempuan sebagai musibah/bencana, dan dalam Islam sebagian ada dua yang merugikan perempuan, yakni mereka yang terlalu tradisionalis dan mereka yang liberalis. Penulis artikel tersebut mengatakan bahwa apa yang menimpah

${ }^{45}$ M.A. Hermawan, "Nilai Moderasi Islam dan Internalisasinya di Sekolah", dalam Insania, Vol. 25, No. 1, 2020.

${ }^{46}$ Hani Hiqmatunnisa dan Ashif Az-Zafi, "Penerapan Nilai-nilai Moderasi Islam dalam Pembelajaran Fiqh di PTKIN Menggunakan Konsep Problem-Based Learning”, dalam JIPIS, Vol. 29, No. 1, 2020.

${ }^{47}$ Nur Salamah, dkk, "Upaya Menyemai Moderasi Beragama Mahasiswa IAIN Kudus melalui Paradigma Ilmu Islam Terapan” dalam Quality, Vol. 8, No. 2, 2020. 
perempuan dalam agama-agama tersebut perlu disadari oleh umat Islam, terutama dalam menyelaraskan ajaran moderasi beragama dalam kasus kesetaraan gender. ${ }^{48}$

Konteks selanjutnya adalah moderasi beragama di media sosial. Artikel pada konteks ini dapat disebutkan pertama adalah "Kampanye Moderasi Beragama di Facebook: Bentuk dan Strategi Pesan" oleh Ari Wibowo. Dalam artikel tersebut, Verbalisasi moderasi beragama terlihat pada upaya Ari Wibowo menawarkan dua strategi moderasi beragama di facebook, pertama dengan berorientasi pada perubahan sikap, perilaku dan pandangan public (ideologically-oriented), kedua, pesan kampanye yang informatif dan persuasif tentang moderasi beragama yang tidak mesti dalam bentuk tulisan, tetapi juga dapat melalui gambar (animasi), ilustrasi, maupun video edukasi. ${ }^{49}$ Artikel selanjutnya berjudul "Media dan Dakwah Moderasi: Melacak Peran Strategi dalam Menyebarkan Faham Moderasi di Situs Nahdlatul Wathan On-Line Situs Kalangan Netizen Muslim-Santri” oleh Fahrurrozi dan Muhammad Thohri. Verbalisasi moderasi beragama dalam artikel tersebut terlihat pada temuannya yang menempatkan netizen (santri/santriwati) yang mengenal aktif konten-konten dakwah yang menyejukkan.Selain itu, pembumian moderasi beragama sangat efektif dengan menggunakan media sosial seperti yang dilakukan oleh Nahdlatul Wathan Online. ${ }^{50}$

Lingkup kajian sarjana PTKIN yang terakhir adalah masa pandemi Covid-19 yang bersinggungan dengan moderasi beragama.Artikel pertama disebutkan di sini adalah "Darurat Moderasi Beragama di Tengah Pandemi Corona Virus Desease (Covid-19)" yang ditulis oleh Abdul Syatar, Muhammad Majdy Amiruddin, dan Arif Rahman. Dalam artikel tersebut, Verbalisasi moderasi beragama terlihat upaya mengaitkan konsep rukhsa dalam Islam (baca: fiqh) dengan penjagaan keselamatan diri dan masyarakat yang terkait wabah Corona. Dari sini, penulis artikel tersebut menilai moderasi beragama mesti dijalankan agar terhindar dari sikap berlebih-lebihan dalam beragama pada era pandemi. ${ }^{51}$ Artikel selanjutnya adalah "Membumikan Nilai-nilai Moderasi Agama di Masa Pandemi (Dalam

\footnotetext{
${ }^{48}$ Meirison, dkk, "Moderasi Islam dalam Kesetaraan Gender (Komparasi terhadap Agama Yahudi dan Nasrani)", dalam Jurnal Al-Ijtimaiyyah: Media Kajian Pengembangan Masyarakat Islam, Vol. 6, No. 1, 2020.

49 Ari Wibowo, "Kampanye Moderasi Beragama di Facebook: Bentuk dan Strategi Pesan", dalam Edugama: Jurnal Kependidikan dan Sosial Keagamaan, Vol. 5, No. 1, 2019.

${ }^{50}$ Fahrurrozi dan Muhammad Thohri, "Media dan Dakwah Moderasi: Melacak Peran Strategis dalam Menyebarkan Faham Moderasi di Situs Nahdlatul Wathan On-Line Situs Kalangan Netizen MuslimSantri”, dalam Tasamuh: Jurnal Komunikasi dan Pengembangan Masyarakat Islam, Vol. 17, No 1, 2019.

${ }^{51}$ Abdul Syatar, dkk, "Darurat Moderasi Beragama di Tengah Pandemi Corona Virus Desease 2019 (Covid-19)”, dalam Kuriositas: Media Komunikasi Sosial dan Keagamaan, Vol. 13, No. 1, 2020.
} 
Perspektif IPS) oleh Deny Miftah M. Nur, Mochammad, dan Risha Fitriani. Verbalisasi moderasi beragama dalam artikel tersebut terlihat pada pengungkapan nilai-nilai moderasi beragama yang digunakan untuk merespon permasalahan terkikisnya nilai-nilai agama selama masa wabah Covid-19. Ketiga penulis artikel ini menilai bahwa mesti ditanamkan nilai-nilai moderasi beragama dalam proses pendidikan, sehingga lahir way of lif (pandangan hidup) selama masa pandemi Covid-19. ${ }^{52}$

\section{KESIMPULAN}

Dari berbagai paparan sebelumnya dapat ditarik kesimpulan bahwa moderasi beragama telah menjadi isu tersendiri yang mengambil perhatian penting bagi sarjana PTKIN, terutama dalam bentuk kajian artikel jurnal.Komitmen untuk menyemarakkan moderasi beragama di Indonesia, sebagaimana yang diarahkan oleh kementrian Agama RI, dalam bentuk artikel jurnal, memberi nuansa tersendiri dan khas bagi sarjana PTKIN.Hal ini karena moderasi beragama dapat dikatakan telah menyentuh sebagian besar wilayah Indonesia melalui kampus-kampusnya.Ada dua puluh tujuh (27) artikel sarjana PTKIN yang ditemukan membahas moderasi beragama dengan ragam perspektif dan ruang lingkupnya.Yang lebih penting adalah hampir seluruh sarjana PTKIN melakukan upaya Verbalisasi terhadap moderasi beragama kepada konteks atau lingkup kajiannya.Dengan Verbalisasi moderasi beragama, berbagai artikel sarjana tersebut mengindikasikan kekontemporeran kajian terhadap moderasi beragama, yang senantiasa merespon berbagai lingkup ruang dan waktu atau shalihu likulli zaman wa makan. Hal ini menjadi sumbangsih penting sarjana PTKIN terhadap upaya menghasilkan pola, penjagaan, hingga pengembangan moderasi beragama di Indonesia, terutama sejak 2016-2020. [] Wallahu A'lam.

${ }^{52}$ Dany Miftah M. Nur, dkk, "Membumikan Nilai-nilai Moderasi Agama di Masa Pandemi (dalam Perspektif IPS)", dalam Harmony, Vol. 5, No. 2, 2020. 


\section{DAFTAR PUSTAKA}

Al-Salabi, Ali Muhammad Muhammad, Al-Wasathiyyah Fi Al-Qur'an Al-Karim (Kairo: Maktabah Al-Tabi'in, 2001).

Arenggoasih, RR. Wuri, dan Corona Raisa Wijayanti, "Pesan Kementrian Agama dalam Moderasi Melalui Media Sosial Instagram”, dalam Jurnalisa, Vol. 6, No. 1, 2020.

Asrori, Saifuddin, "Lanskap Moderasi Keagamaan Santri, Refleksi Pola Pendidikan Pesantren”, dalam Jurnal Ilmu Sosial Indonesia (JISI), Vol. 1, No. 1, 2020.

Awwaliyah, Neny Muthi'atul, "Pondok Pesantren sebagai Wadah Moderasi Islam di Era Generasi Millenial", dalam Islamic Review: Jurnal Riset dan Kajian Keislaman, Vol. 8, No. 1, 2019.

Busyro, dkk, "Moderasi Islam (Wasathiyyah) di Tengah Pluralisme Agama Indonesia", dalam Fuadana: Jurnal Kajian Keagamaan dan Kemasyarakatan, Vol. 3, No. 1, 2019.

Darajat, Zakiyah, "Muhammadiyah dan NU: Penjaga Moderatisme Islam di Indonesia", dalam Hayulah: Indonesian Journal of Multidisciplinary Islamic Studies, Vol. 1, No. 1, 2017.

Darlis, "Mengusung Moderasi Islam di tengah Masyarakat Multi Kultural", dalam Rausyan Fikr, Vol. 13, No. 2, 2017. , "Peran Pesantren As'adiyah Sengkang dalam Membangun Moderasi Islam di

Tanah Bugis (Sebuah Penelitian Awal)", dalam Al-Misbah, Vol. 12, No. 1, 2016.

Departemen Agama RI, Etika Berkeluarga, Bermasyarakat dan Berpolitik, Cet. 1 (Jakarta: Lajnah Pentashihan Mushaf Al-Qur'an, 2009).

Fahri, Mohamad, dan Ahmad Zainuri, "Moderasi Beragama di Indonesia", dalam Intizar, Vol. 25, No. 2, Desember 2019.

Fahrurrozi dan Muhammad Thohri, "Media dan Dakwah Moderasi: Melacak Peran Strategis dalam Menyebarkan Faham Moderasi di Situs Nahdlatul Wathan On-Line Situs Kalangan Netizen Muslim-Santri”, dalam Tasamuh: Jurnal Komunikasi dan Pengembangan Masyarakat Islam, Vol. 17, No 1, 2019.

Faruq Thohir, Umar, 2016. "Paradigma Hukum Islam; Dari Klasik Menuju Kontemporer”. Asy-Syari'ah : Jurnal Hukum Islam 2 (2). 
Fatmawati, Fatimah, "Studi Penelitian Tafsir di Indonesia (Pemetaan Karya Tafsir Indonesia Periode 2011-2018)" dalam Al-Tadabbur: Jurnal Kajian Sosial, Peradaban dan Agama, Vol. 6, No. 1, 2020.

Fauzi, Ahmad, "Moderasi Islam, untuk Peradaban dan Kemanusiaan”, dalam jurnalIslam Nusantara, Vol. 2, No. 2, 2018.

Fina, Lien Iffah Naf'atu, "Interpretasi Kontekstual Abdullah Saeed: Sebuah Penyempurnaan Terhadap Gagasan Tafsir Fazlur Rahman", dalam Jurnal Hermeneutik, Volume 9, Nomor 1, 2015.

Fuad, A. Jauhar, "Akar Sejarah Moderasi Islam pada Nahdlatul Ulama”, dalam Tribakti: Jurnal Pemikiran Keislaman, Vol. 31, No. 1, 2020.

Gadamer "Text and Interpretation" dalam B.R. Wachterhauser (ed), Hermeneuticand Modern Philosohpy, (New York: Albany State Universityof New YorkPress, 1986).

Hariyah, "Research Trends in Islamic Studies on Journal of Research and Development and Training Center Ministry of Religious Affairs: Using Co-Words", dalam Record and Library Journal, Vol. 2, No. 2, 2016.

Hasibuan, Hamka Husein, "Moderasi Islam, Pencantuman Penghayat Kepercayaan di Kolom KTP/KK dalam Nalar Maqasid”, dalam Al-Qalam: Journal of Islam and Plurality, Vol. 4, No. 2, 2019.

Hermawan, M.A. "Nilai Moderasi Islam dan Internalisasinya di Sekolah", dalam Insania, Vol. 25, No. 1, 2020.

Hiqmatunnisa, Hani dan Ashif Az-Zafi, "Penerapan Nilai-nilai Moderasi Islam dalam Pembelajaran Fiqh di PTKIN Menggunakan Konsep Problem-Based Learning”, dalam JIPIS, Vol. 29, No. 1, 2020.

HS, Muh. Alwi, “Kelisanan Al-Qur'an dan Karakteristik Pemahamannya (Kajian QS.AlKafirun)", Tesis UIN Sunan Kalijaga Yogyakarta, 2020. , “Diskursus Kelisanan Al-Qur'an: Membuka Ruang Baru”, dalam Journal of Islamic Studies and Humanities, vol. 4, no. 2, 2020.

, "Mewujudkan Perdamaian di Era Media Versi KH. Maimun Zubair: Analisis Ma'na-cum-Maghza atas Pesan KH. Maimun Zubair di Media Sosial”, dalam Madinah: Jurnal Studi Islam, Vol. 6, No. 2, 2019. 
, 'Relasi Kelisanan Al-Qur'an dan Pancasila dalam Upaya Menjaga dan Mengembangkan Identitas Islam Indonesia”, dalam International Journal Ihya Ulum Al-Din, vol. 21, no. 1, 2020.

, "Verbalisasi Al-Qur'an dan Nilai Pancasila: Legitimasi Surah Al-Maidah/5: 49”, dalam Jurnal Suhuf, vol. 12, no. 2, 2019.

, "Verbalisasi Al-Qur'an dan Nilai Pancasila: Legitimasi Surah Al-Maidah/5:49”, dalam Jurnal Suhuf, vol. 12, No. 2, 2019.

, dan Iin Parninsih, "Verbalisasi Al-Qur'an: Metode Tafsir Kontekstual Berbasis Kelisanan Al-Qur'an (Studi QS. Al-Baqarah: 156 tentang Pemaksaan Agama)”, dalam Substantia: Jurnal Ilmu-ilmu Ushuluddin, Vol. 22, No. 2, 2020.

- Pengantar Al-Qur'an dan Hadis untuk Indonesia: Upaya Membaca sisi Kelisanan Al-Qur'an dan Hadis, (Yogyakarta: Deepublish, 2018).

http://diktis.kemenag.go.id/aicis/2018/index.php/2018/10/05/ini-lima-poin-hasilpertemuan-sarjana-muslim-dunia/ diakses pada 27 November 2019.

http://diktis.kemenag.go.id/aicis/index.php/2019/10/06/aicis-2019-tiga-rekomendasi-

sikapi-fenomina-digital-islam/ diakses pada 27 November 2019.

https://ldikti12.ristekdikti.go.id/2012/02/01/surat-dirjen-dikti-no-152et2012-tentangwajib-publikasi-ilmiah-bagi-s1s2s3.html diakses pada 27 November 2019.

Huda, Nailil dan Ade Pahrudin, "Orientasi Kajian Hadis Kontemporer Indonesia (Studi Artikel E-Jurnal dalam Portal Moraref 2015-2017”, dalam Refleksi, Vol. 17, No. 2, 2018.

Irawan, Mohammad Deny, “Islam Wasatiyyah: Refleksi Antara Islam Modern dan Upaya Moderasi Islam”, dalam Tajdid, Vol. XVI, No. 2, 2017.

Islam, Khalil Nurul, "Moderasi Beragama di Tengah Pluralitas Bangsa: Tinjauan Revolusi Mental Perspektif Al-Qur'an”, dalam Kuriositas: Media Komunikasi Sosial dan Keagamaan, Vol. 13, No. 1, 2020.

Kamali, Mohammad Hashim, The Middle Path of Moderation in Islam: the Qur'anic Principle of Wasathiyyah (New York: Oxford University Press, 2015).

Khikmatiar, Azkiya, "Reinterpretation of the Hadith of Tashabbuh: Application of the Double Movement Fazlur Rahman's Theory in Understanding the Hadith" dalam Journal of Hadith Studies, Volume 1 Nomor 1, 2018. 
Khoiri, Ahmad, "Moderasi Islam dan Akulturasi Budaya: Revitalisasi Kemajuan Peradaban Islam Nusantara", dalam Islamadina: Jurnal Pemikiran Islam, Vol. 20, No. 1, 2019.

Meirison, dkk, "Moderasi Islam dalam Kesetaraan Gender (Komparasi terhadap Agama Yahudi dan Nasrani)", dalam Jurnal Al-Ijtimaiyyah: Media Kajian Pengembangan Masyarakat Islam, Vol. 6, No. 1, 2020.

Mubarok, Ahmad Agis, dan Diaz Gandara Rustam, "Islam Nusantara: Moderasi Islam di Indonesia”, dalam Journal of Islamic Studies and Humanities, Vol. 3, No. 2, 2018.

Mustaqim, Abdul, Al-Tafsir Al-Maqashidi, (Yogyakarta: Idea Press, 2019).

Nur, Dany Miftah M. dkk, "Membumikan Nilai-nilai Moderasi Agama di Masa Pandemi (dalam Perspektif IPS)", dalam Harmony, Vol. 5, No. 2, 2020.

Rahman, Fazlur, Islam and Modernitiy: Transformation of an Intellectual Tradition, (Chicago: Chicago University Press, 1982).

Saeed, Abdullah, Reading the Qur'an in the Twenty-First Century: A Contextualist Approach, (Oxon and New York: Routledge, 2014).

Saifuddin, Lukman Hakim, "Sambutan Mentri Agama Republik Indonesia" dalam Tim Penyusun Kementrian Agama RI. Moderasi Beragama, (Jakarta: Kementrian Agama RI, 2019).

, “Sambutan Mentri Agama Republik Indonesia" dalam Tim Penulis, Mozaik Moderasi Beragama dalam Perspektif Islam, (Jakarta: Direktorat Jenderal Bimbingan Masyarakat Kristen Kementrian Agama Republik Indonesia, 2018).

Salamah, Nur, dkk, "Upaya Menyemai Moderasi Beragama Mahasiswa IAIN Kudus melalui Paradigma Ilmu Islam Terapan” dalam Quality, Vol. 8, No. 2, 2020.

Syamsuddin, Sahiron, Hermeneutika dan Pengembangan Ulumul Qur'an (edisi Revisi dan Pengembangan), (Yogyakarta: Pesantren Nawesea Press, 2017).

Syatar, Abdul, dkk, "Darurat Moderasi Beragama di Tengah Pandemi Corona Virus Desease 2019 (Covid-19)", dalam Kuriositas: Media Komunikasi Sosial dan Keagamaan, Vol. 13, No. 1, 2020.

Wibowo, Ari, “Kampanye Moderasi Beragama di Facebook: Bentuk dan Strategi Pesan”, dalam Edugama: Jurnal Kependidikan dan Sosial Keagamaan, Vol. 5, No. 1, 2019. 